Indonesian Journal of EFL and Linguistics

Vol. 2 No. 2, 2017

eISSN: 2503-4197, pISSN: 2527-5070

www. indonesian-efl-journal.org

\title{
Students' Perspectives towards Innovation of Technology in Teaching and Learning of Language
}

\author{
${ }^{1}$ Nor Shahila Mansor, Hazlina Abdul Halim, Normaliza Abd Rahim \\ Faculty of Modern Languages and Communication \\ Universiti Putra Malaysia (MALAYSIA) \\ ${ }^{1}$ Corresponding author: nsm@upm.edu.my
}

\begin{abstract}
:
This study provides a discussion of the innovations, in particular students' perspectives towards the use of technology in teaching and learning. The study aimed to (1) identify methods of teaching and learning that can be applied in the classroom to engage students, (2) to determine factors in selecting the methods of teaching and learning by respondents. The data of this study were collected through questionnaire. The respondents of the study consisted of 150 undergraduate students from various programs aged between 19 and 23 at Universiti Putra Malaysia. The race or ethnicity of the respondents is disregarded as it is irrelevant to the objectives of the study. The results were presented in qualitative and quantitative. From 7 types or options of technological innovation listed, all of the respondents $(100 \%)$ tend to prefer the use of various media as well as computer-assisted teaching as innovations in teaching and learning. Meanwhile, a total of 139 respondents (93\%) prefer the use of overhead projector and the use of VCD in the classroom. 123 students (82\%) choose the video teleconferencing approach, 113 students (75\%) choose the use of interactive video and 90 of the respondents (60\%) favour the use of printed media such as advertisements in newspapers, magazines and etc. In line with the development of technology, innovation in teaching and learning is viewed as a prerequisite in optimizing the output of education. This study also shows to the importance of the innovation to ensuring the continuity of education.

Keyword: Innovation, technology, teaching and learning, continuity of education
\end{abstract}

Indonesian Journal of EFL and Linguistics, 2(2), 2017 


\section{INTRODUCTION}

In order to ensure continuity of education, innovation in teaching and learning is essential. Innovation in teaching and learning needs to be done at all stages from the management and administration up to the implementation stage. In response to the government's call to establish Malaysia as a hub for education, innovation in teaching and learning should not be taken lightly. Innovation enables educational institutions such as universities and schools to keep pace with the current world development.

Innovation in education can be seen as an attempt to reform the teaching and learning process performed by a group of individuals. According to Carless (2013), an example of educational innovation that has been done in this decade is the new pedagogical approaches such as 'task-based' language teaching, exchange of teaching material, the use of technology such as computer-based teaching as well as alternative assessment methods. In addition, the expanded use of language options (English for example) as the medium of instruction in educational institutions, including the primary level is also an element of educational innovation.

Innovation is an important step as it is fundamental to the development and advancement of education. Innovation viewed as a process of improvement, to the existing system or practice. In other words, the implementation of innovation will not change the primary principle of a system or practice, but it will improve it (Waters, 2009). Markee (1997) categorizes the innovation of education into two types: Primary innovation and secondary innovation. Primary innovation involves changes in teaching materials and pedagogy, whereas secondary innovation involves organizational changes that provide support for the primary innovation. As limitation of the study, this paper focuses only on the primary innovation.

Usually, instructors either at school or university conduct the process of teaching and learning by using teaching aids deemed suitable for students. The educators would apply the approach and teaching techniques that they learned in teacher education institute or university (Yahya Buntat \& Lailinanita Ahamad, 2012). However, the methods used by the educators in the classroom are not necessarily compatible with the student's requirements, needs and aptitude. As a consequence, the student cannot comprehensively follow the process of teaching and learning because those methods do not appeal to their interests.

Thus, this paper will discuss the methods that are more attractive to students among the list of methods of innovation, particularly technological innovation. In addition, this study also reviews the factors that cause the students more likely to opt a particular method, for example opting for A method compared to B method.

\subsection{Innovation in Teaching and Learning}

The study of innovation in teaching and learning began around 1980 (Carless, 2013). Research on innovation in language education, particularly in English language is pioneered by scholars such as Kennedy (1988), which focuses on the perspective of 
teaching of English in the United Kingdom and Henrichsen (1989), which views the perspective of English language education in the United States.

In implementing and ensuring the success of an innovation, a teacher or an educator should have a solid understanding of the methods that will be used. Lack of training and exposure to teachers is also one of the factors that led to the failure of the innovation process in an educational institution (Azizah Abdul Rahman, 1987). The shift of era also led to changes in the educational system, from the 'chalk and talk', to technology-assisted teaching, the use of overhead projectors, OHP, media and so forth. Therefore, teachers' understanding and openness to some extent would help in implementing the innovation process to perfection. In addition, their passion and trust are also important in determining the success of the implementation process of innovation in teaching and learning (Clark \& Yinger, 1977). In this regard, the failure of teacher to interpret the purposes of innovation would also cause the changes in the process of teaching and learning less successful (Brown \& McIntyre, 1933).

According to Carless (2013), there are also challenges in ensuring the success of the educational innovation process, much the same as the process of reformation in other fields. These challenges are classified into 3 categories:

- Teacher-related challenge: this challenge involves issues such as the negative attitude of some teachers towards innovation, lack comprehension of the innovation concept, contradiction between the innovation concept with practices and existing principles, perceive innovation as a change that would only increase the workload, hence it becomes a threat to career a teacher.

- System-related challenge: miscommunication between the drafters and the implementers of innovation, overemphasize on the theory but not in the practice, namely emphasis too much on the ins and outs of the innovation process (in the paper) and have no specific focus on how innovation should be implemented, lack of appropriate resources to help the innovation trial, insufficient training of the implementers such as teachers and lecturers, and the failure to adapt the pedagogical practices and assessment practices.

- School-related challenge: lack of positive culture towards innovation, fixed with conservative practices or traditional in educational institutions, the management of the educational institutions do not offer decent opportunities to the implementers, the use of inappropriate educational resources that would cause the students hard to accept the changes.

Yahya Buntat \& Lailinanita Ahamad (2012) conducted a study on innovation in teaching and learning among technical teachers of secondary technical schools in Malaysia. The study was carried out to identify teacher's perspective on innovations in teaching and learning. There are four aspects emphasized in this study: the practice of innovation in teaching and learning in schools, the type of training that was attended by technical teachers, factors that become obstacles and opportunities or incentives for technical school teachers in implementing innovation in schools. 
Based on the results of the study, it was found that the teachers teaching in technical schools have adopted several innovations in teaching and learning. Furthermore, technical school teachers in Malaysia are also given proper training and exposure to smoothen the application of innovation process in schools. Furthermore, the study found that there are some obstacles in the implementation of innovation in schools, for instance, there are a number of teachers who are unprepared to implement innovations. Time constraints and lack of interest make the teachers do not get adequate exposure hence become one of the limiting factors of innovation among teachers in the technical school. Overall, it can be concluded that innovation in the technical school was successfully done with the support and full cooperation from the school management.

Technological innovations can be categorized as sub-skills of the 21 st century and it is a necessity that must be instilled in students to meet the demands of the emerging digital era. According to Wahyu Idayu \& Yahya Buntat (2002), technological innovations include the use of electronic networks such as the Internet, intranet, interactive $\mathrm{tv}$, the emerging digital text, animation, graphics, simulations, video as well as audio. Technological innovation also allows students to learn independently at appropriate time and in accordance with their capabilities (Rahimi Md Saad, Zawawi Ismail \& Wan Nordin Wan Abdullah, 2005). Furthermore, technological innovation also saves time and teacher's energy in providing teaching and learning materials.

The innovation in teaching a foreign language will bring effects to the students' motivation in class. According to $\mathrm{Bi}$ (2005), the positive learning enviroment including the support from the intructors will stimulate the students' interest in acquaring a foreign language. Lund (2004) states that, "technologies increasingly form a crucial part of the learning enviroment". Consequently, by using the technology, the foreign language instructors are able to presented the material in a creative manner and by doing that they help the development of cognitive processes (Camilleri, 2000).

\section{RESEARCH METHODOLOGY}

The study was conducted by using descriptive qualitative method. The data were obtained from questionnaires. Respondents consisted of undergraduate students from various programs who enroll in foreign language courses at the Faculty of Modern Languages and Communication, Universiti Putra Malaysia. A total of 150 respondents aged between 19-23 years were asked to answer the questionnaire. 100 respondents were female and the rest 50 are male students. The gender imbalance is not a problem as it is not relevant to the objectives of this study. Since the number of respondents is not too large, the percentage was calculated manually without using any support software.

\section{THEORETICAL PERSPECTIVE}

Haverlock (1971) has listed five variables that support innovation which are attributes or characteristics of innovation, types of innovation decisions, communication channels, the natural characteristic of the social system and the role 
of agents of change. In this study, only the first variable is accounted since other variables are not correspond to the objectives of the study.

Attributes of innovation can be defined as characteristics or factors that support the innovation. There are five characteristics of innovation that would lead to social acceptance:

- Has a relative advantage - relative advantage refers to something that is better. Briefly, something that is innovated should be more advance than the existing ones. For example, the use of an overhead projector is more advance than the use of chalk and whiteboard.

- Compatible with receivers - the compatibility in terms of teaching and learning, includes the compatibility of ideas, practices or materials used by teachers with the needs of the teachers and students at a time. For example the use of computer-assisted instruction in this age of technology and internet is seen more practical than the use of textbooks.

- Does not cause complexity - innovation introduced should not cause difficulties to the adopters or require them to have additional skills.

- Easy to try - early exposure to an innovation could appeal to teachers' and students' interest.

- Easy to observe - positive effects, increased learning outcomes and improvement in exam grades could be felt by teachers and students after the use of innovation that is introduced.

These five aspects of innovation attributes are listed in the questionnaire and respondents were asked to make a selection based on their needs and personal experience as a student who is taking foreign language proficiency course.

\section{FINDINGS}

This section discusses the types of approaches and methodologies of innovation, particularly technological innovation which is attempted to be applied in teaching and learning. Moreover, the tendency of students to choose a particular method of technological innovation compared to other methods is also discussed.

\subsection{Innovation in Teaching and Learning of Language: Approaches and Methodologies}

\subsubsection{Communicative method vs Traditional method}

Communicative method began to grow in the 1970's. Communicative method in teaching and learning of language was introduced, considering the traditional method that is less helpful in students performance as it tend to use textbooks and emphasis on grammar as well as translation (Burn \& Joyce, 1999).

The data obtained showed that 120 respondents $(80 \%)$ prefered communicative compared to the traditional approach. 


\subsubsection{The use of technology vs. traditional teaching}

The second part of the questionnaires dealt with the tendency of students on teaching and learning methods used in classroom. To answer the question in this section, the researchers gives preference for students to choose whether they are more likely to use technology (the use of online websites, the use of CD-ROM, video from 'youtube' channel, film and animation, online chatting, the use of online dictionary and also 'google translate'). Whereas the second option focuses solely on the use of textbooks and exercise books (with or without picture) as well as printed advertisement clipping either from the the newspaper or magazines.

The survey data showed that the majority of respondents, a total of 135 students (90\%) tend to choose the first option: the use of technology. The remaining respondents, a total of 15 students $(10 \%)$ are still comfortable with the second option: the use of textbooks. the respondents are interested more in using the technology in learning a foreign language because the technology is integrated in almost every aspects of our life (Marcinek, 2014).

\subsection{Type of Technological Innovation in Teaching and Learning}

Under the big umbrella of technology there are many of tools, among other a projector, videos and online dictionaries (Negoescu \& Boştină-Bratu, 2016). In the questionnaire, there was a list of 7 options of technological innovation in teaching and learning: the use of overhead projector, the use of various social media, computer-assisted teaching, video teleconferencing method, the use of interactive video, VCD and also the use of printed media. Each of the respondents were asked to answer the questionnaires and they were allowed to choose more than one answer.

Table 1: List of technological innovations in teaching and learning

\begin{tabular}{|c|l|c|c|}
\hline No. & Types of technological innovations & $\begin{array}{c}\text { Number of } \\
\text { respondents }\end{array}$ & $\begin{array}{c}\text { Percentage } \\
(\%)\end{array}$ \\
\hline 1. & Use of overhead projector & 139 & 93 \\
\hline 2. & $\begin{array}{l}\text { Use ov various social media includes laman } \\
\text { website, social chat site, 'blogspot' and etc. }\end{array}$ & 150 & 100 \\
\hline 3. & Computer-assisted teaching & 150 & 100 \\
\hline 4. & Video teleconferencing method & 123 & 82 \\
\hline 5. & $\begin{array}{l}\text { The use of interactive video for example } \\
\text { from 'youtube' }\end{array}$ & 113 & 75 \\
\hline 6. & $\begin{array}{l}\text { The use of VCD (screening of film and TV } \\
\text { series) }\end{array}$ & 139 & 60 \\
\hline 7. & $\begin{array}{l}\text { The use of printed media such as printed } \\
\text { advertisements, articles in magazines and } \\
\text { newspapers. }\end{array}$ & 90 & \\
\hline
\end{tabular}

Table 1 above indicates the seven types of innovation involving the use of technology in teaching and learning of foreign language. As stated earlier, in answering this questionnaire the respondents could select more than one answer for this section. From the questionnaire returned to the researchers, all 150 respondents $(100 \%)$ tend to choose the use of various media and computer-assisted teaching. In 
addition, 139 (93\%) respondents chose the use of overhead projector, $123(82 \%)$ of the respondents prefer the method of teleconferencing video, $113(75 \%)$ respondents chose the use of interactive video, 139 (93\%) respondents chose the use of VCD and only 90 ( $60 \%$ ) of the respondents chose the use of printed media.

\subsection{Acceptance Factors of Method of Teaching and Learning}

Havelock (1971) listed five variables that could influence the adoption and implementation of innovation: the attributes or characteristics of innovation, types of innovation decisions, communication channels, the natural characteristic of social system and the role of change agents. In the questionnaire, the researchers only focused on the first variable which is the attributes or characteristics of innovation, since other variables are not correspond to the objectives of the study. . To view the aspects that could make the respondent accept an innovation, the researchers have listed five characteristics of innovation: has relative advantage, compatible with receiver, does not cause complexity, easy to try and easy to observe as suggested by Havelock (1971).

Table 2: The Number of Respondents who Choose the Use of overhead projector and the factors of selection

\begin{tabular}{|l|l|l|c|c|}
\hline No. & $\begin{array}{l}\text { Type of technological } \\
\text { innovation }\end{array}$ & Factors of selection & $\begin{array}{c}\text { Number of } \\
\text { respondents }\end{array}$ & $\begin{array}{c}\text { Percentage } \\
(\%)\end{array}$ \\
\hline \multirow{3}{*}{$\begin{array}{l}\text { The use of overhead } \\
\text { projector }\end{array}$} & Has relative advantage & 43 & 31 \\
\cline { 2 - 4 } & Compatible with receiver & 29 & 21 \\
\cline { 2 - 4 } & Does not cause complexity & 34 & 24 \\
\cline { 2 - 4 } & Easy to try & 22 & 16 \\
\cline { 2 - 4 } & Easy to observe Total & 11 & 8 \\
\hline
\end{tabular}

Table 2 above shows the number of respondents that tend to prefer the use of overhead projector as a method of teaching and learning. Of the 139 respondents, 43 of them $(31 \%)$ prefer the use of overhead projector because it has relative advantage. Whereas 34 respondents $(24 \%)$ prefer this method because it does not cause complexity. 29 respondents $(21 \%)$ choose this method as it is compatible with the receiver, 22 respondents $(16 \%)$ choose it because it is easy to try and the remaining number of 11 respondents $(8 \%)$ believe that this method is easy for observation.

Table 3: The Number of Respondents who Choose the Use of various media and the factors of selection

\begin{tabular}{|l|l|l|c|c|}
\hline No. & $\begin{array}{l}\text { Type of technological } \\
\text { innovation }\end{array}$ & Factors of selection & $\begin{array}{c}\text { Number of } \\
\text { respondent }\end{array}$ & $\begin{array}{c}\text { Percentage } \\
(\%)\end{array}$ \\
\hline \multirow{2}{*}{$\begin{array}{l}\text { The use of various } \\
\text { media }\end{array}$} & Has relative advantage & 43 & 29 \\
\cline { 2 - 5 } & Compatible with receiver & 29 & 19 \\
\cline { 2 - 5 } & Does not cause complexity & 23 & 15 \\
\cline { 2 - 5 } & Easy to try & 44 & 30 \\
\cline { 2 - 5 } & Easy to observe Total & 11 & 7 \\
\hline
\end{tabular}

Indonesian Journal of EFL and Linguistics, 2(2), 2017 
Table 3 above shows the number of respondents who choose the use of various media, as technological innovation. The data shows all 150 respondents tend to prefer this type of innovation in teaching and learning foreign languages. The number of respondents who choose the use of various media because it has a relative advantage is 43 respondents (29\%). 29 respondents (19\%) choose the use of various media because it is compatible with the receiver and 23 respondents $(15 \%)$ choose it because it does not cause complexity. Of the 150 respondents, a total of 44 respondents $(30 \%)$ opt this method because of its features which is easy to try and only a total of 11 respondents (7\%) opt it as it is easy to observe.

Table 4: The Number of Respondents who Choose the method of computer-assisted teaching and the factors of selection

\begin{tabular}{|l|l|l|c|c|}
\hline No. & $\begin{array}{l}\text { Type of technological } \\
\text { innovation }\end{array}$ & Factors of selection & $\begin{array}{c}\text { Number of } \\
\text { respondent }\end{array}$ & $\begin{array}{c}\text { Percentage } \\
(\mathbf{\%})\end{array}$ \\
\hline \multirow{3}{*}{3.} & \multirow{2}{*}{$\begin{array}{l}\text { Computer-assisted } \\
\text { teaching }\end{array}$} & Has relative advantage & 41 & 27 \\
\cline { 3 - 5 } & Compatible with receiver & 35 & 23 \\
\cline { 3 - 5 } & Does not cause complexity & 22 & 15 \\
\cline { 3 - 5 } & Easy to try & 38 & 25 \\
\cline { 3 - 5 } & Easy to observe Total & 14 & 10 \\
\hline
\end{tabular}

Table 4 above shows the data of computer-assisted teaching method. As well as the the use of various media, computer-assisted teaching method is also a major preference of respondents. The data shows that all of the respondents tend to choose this method as a teaching aid in learning of foreign language class. Out of 150 people, a total of 41 respondents $(27 \%)$ choose the method of computer-assisted teaching because it has relative advantage. 35 respondents $(23 \%)$ choose it considering its compatibility with the receivers, while 22 respondents $(15 \%)$ opt this method because it does not cause complexity. In addition, 38 respondents (25\%) believes that this method is easy to try and the remaining respondents, 14 respondents $(10 \%)$ opt this type of technological innovation as it is easy for observation.

Table 5: The Number of Respondents who Choose the method of video teleconferencing and the factors of selection

\begin{tabular}{|l|l|l|c|c|}
\hline No. & $\begin{array}{l}\text { Type of technological } \\
\text { innovation }\end{array}$ & Factors of seletion & $\begin{array}{c}\text { Number of } \\
\text { respondent }\end{array}$ & $\begin{array}{c}\text { Percentage } \\
(\mathbf{\%})\end{array}$ \\
\hline \multirow{4}{*}{4.} & Video teleconferencing & Has relative advantage & 11 & 9 \\
\cline { 3 - 5 } & & Compatible with receiver & 12 & 10 \\
\cline { 2 - 5 } & & Does not cause complexity & 32 & 26 \\
\cline { 2 - 5 } & Easy to try & 35 & 28 \\
\cline { 2 - 5 } & Easy to observe Total & 33 & 27 \\
\hline
\end{tabular}

A total of 123 of the respondent choose video teleconferencing as a method of innovation in teaching and learning. As shown in Table 5, 35 respondents (28\%) 
choose the method of video teleconferencing as it is easy to try, 33 respondents (27\%) choose it because it is easy to observe and 32 respondents $(26 \%)$ select this method as it does not cause complexity. Data shows that only 11 respondents $(9 \%)$ choose this method because it has relative advantages and the remaining 12 respondents $(10 \%)$ opt it as it is compatible with the receiver.

Table 6: The Number of Respondents who Choose the use of interavtive video and the factors of selection

\begin{tabular}{|l|l|l|c|c|}
\hline No. & $\begin{array}{l}\text { Type of technological } \\
\text { innovation }\end{array}$ & Factors of seletion & $\begin{array}{c}\text { Number of } \\
\text { respondent }\end{array}$ & $\begin{array}{c}\text { Percentage } \\
(\mathbf{\%})\end{array}$ \\
\hline \multirow{3}{*}{5.} & $\begin{array}{l}\text { The use of interactive } \\
\text { video }\end{array}$ & Has relative advantage & 28 & 25 \\
\cline { 2 - 4 } & Compatible with receiver & 19 & 17 \\
\cline { 2 - 4 } & Does not cause complexity & 17 & 15 \\
\cline { 2 - 4 } & Easy to try & 21 & 18 \\
\cline { 2 - 4 } & Easy to observe Total & 113 & 25 \\
\hline
\end{tabular}

Table 6 shows the number of respondents who choose the use of interactive video as a technological innovation. Out of 113 respondents choosing this method, a total of 28 respondents $(25 \%)$ choose it because it has relative advantages whereas the same number of 28 respondents $(25 \%)$ choose it as it is easy to observe. Of the remaining respondents, 19 of them $(17 \%)$ prefer this method as it is compatible with the receiver, 17 respondents $(15 \%)$ choose it because it does not cause complexity and 21 respondents $(18 \%)$ believe that it is easy to try.

Table 7: The Number of Respondents who Choose the use of VCD and the factors of selection

\begin{tabular}{|l|l|l|c|c|}
\hline No. & $\begin{array}{l}\text { Type of technological } \\
\text { innovation }\end{array}$ & Factors of seletion & $\begin{array}{c}\text { Number of } \\
\text { respondent }\end{array}$ & $\begin{array}{c}\text { Percentage } \\
(\mathbf{\%})\end{array}$ \\
\hline 6. & \multirow{2}{*}{ The use of VCD } & Has relative advantage & 39 & 28 \\
\cline { 3 - 5 } & & Compatible with receiver & 32 & 23 \\
\cline { 3 - 5 } & Does not cause complexity & 24 & 17 \\
\cline { 3 - 5 } & Easy to try & 22 & 16 \\
\cline { 3 - 5 } & Easy to observe Total & 22 & 16 \\
\hline & \multicolumn{2}{|r}{139} & 100 \\
\hline
\end{tabular}

A total of 139 respondents choose to adopt the use of VCD in the process of teaching and learning. Table 7 shows the total of 39 respondents $(28 \%)$ who choose this method because it has relative advantage. 32 respondents $(23 \%)$ assume that this method is compatible with the receiver, and 24 respondents (17\%) agree this method does not cause complexity. Whereas, the number of respondents selecting 'easy to try' and 'easy to observe' are equal, which is 22 respondents (16\%). 
Table 8: The Number of Respondents who Choose the use of printed media and the factors of selection

\begin{tabular}{|l|l|l|c|c|}
\hline No. & $\begin{array}{l}\text { Type of technological } \\
\text { innovation }\end{array}$ & Factors of seletion & $\begin{array}{c}\text { Number of } \\
\text { respondent }\end{array}$ & $\begin{array}{c}\text { Percentage } \\
(\boldsymbol{\%})\end{array}$ \\
\hline \multirow{3}{*}{7.} & \multirow{2}{*}{ The use of printed media } & Has relative advantage & 18 & 20 \\
\cline { 3 - 5 } & & Compatible with receiver & 16 & 18 \\
\cline { 3 - 5 } & Does not cause complexity & 21 & 23 \\
\cline { 3 - 5 } & Easy to try & 19 & 21 \\
\cline { 3 - 5 } & Easy to observe & 16 & 18 \\
\hline & \multicolumn{2}{|r}{ Total } & 90 & 100 \\
\hline
\end{tabular}

Table 8 shows the number of respondents who prefer the use of printed media in teaching and learning of foreign language. This method is the least preferred method for technological innovation compared to other methods. There are only 90 respondents selecting the use of printed media and out of these respondents, a total of 21 respondents $(23 \%)$ choose it because it does not cause complexity. 18 respondents $(20 \%)$ choose this method as it has relative advantage and 19 respondents $(21 \%)$ consider that it is easy to try.

\section{CONCLUSION}

From the results, it can be concluded that innovation in teaching and learning is essential in ensuring the continuity of education. Young generation is more inclined towards online education as compared to conventional education. Innovation in teaching is an added value to increase students' motivation in learning languages. The language acquisition and learning in schools and universities are a stepping stone in realizing government policy to establish Malaysia as a multi-lingual country.

Based on the answers of the respondents in the questionnaires, these variables are indeed significance in the acceptance of innovation for teaching and learning of languages. Among the factors that influnece respondents' preference on the use of technology in teaching and learning of languages is the accessibility of the learning materials. The factor of unlimited access of information is also one of the stimulant that causes the respondents tend to prefer the use of technology as compared to the use of textbooks. Broadband services (wifi) facility provided by university also catalyze the tendency of students to choose technology as a teaching aid in foreign language proficiency. With the advent of broadband services that can be accessed at any time and anywhere, the motivation for students to learn the target language is boosted.

In addition, the use of films and videos in the classroom provides more opportunities for students to learn and experience the real situation of the culture and the language they study. The language intructors can engage students outside the classroom by using the videos. Film and video screening to students would also expose them to the application of the target language in the actual communication and help to stimulated learners' interest. Students' access to native speakers of the target language is very limited. Therefore, the access to online chat ("online chat', 
'facebook' and 'blog') provides opportunities for students to communicate with native speakers of the language. It also helps students to learn and comprehend the target language 'naturally'. Outside classroom learning environment makes the students more enthusiastic and motivated in learning foreign languages.

This is due to the fact that textbook-based learning provides a fairly limited opportunity for students to learn and experience the real application of the language. On the contrary, online input enable the students to access the information without boundaries and allow them to experience live chat with the native speakers of the language through the application of 'online chat'.

\section{REFERENCES}

Azizah Abdul Rahman. (1987). Curriculum innovation in Malaysia: The case of the KBSR. Unpublished PhD Thesis, University London: Institute of Education.

Bi, X.F. (2015). Associations between psychosocial aspects of English classroom enviroments and motivation types of Chinese tertiary-level English majors. Learning Environment, 519082, 96-110.

Brown, S. \& McIntyre, D. (1933). Making sense of teaching. USA: Open University Press.

Burns, A. \& Joyce, H. (1999). Focus on speaking. Syedney: National Centre for English Language and Research Macquarie University.

Camilleri, A. (2000). The development of cognitive processes in Anne-Brit Fenner and David Newby (eds.) Approaches to Materials Design in European Textbooks: Implementing Principles of Authencity, Learner Autonomy, Cultural Awareness. European Centre for Modern Languages/Council of Europe: Strasbourg.

Carless, D. (2013). Innovation in language teaching and learning. In Chapelle, C.A. (ed.), The encyclopedia of applied linguistics. Blackwell Publishing Ltd. DOI: 10.1002/9781405198431.wbea10540

Clark, C.M. \& Yinger, R.J. (1977). Research on teaching thinking. USA: Open University Press.

Havelock, R.G. (1971). The change agent: Guide to innovation in education. Englewood Cliff, NJ: Educational Technology Publication.

Henrichsen, L.E. (1989). Diffusion of innovations in English language teaching: The ELEC effort in Japan, 1956-1968. New York, NY: greenwood.

Kennedy, C. (1988). Evaluation of the management of change in ELT projects. Applied Linguistics, 9(4), 329-342.

Lund, A. (2004). Teachers as agents of change: ICTs and a reconsideration of teacher expertise in Anthony Fitzpatrick and Lev Gordon (eds.) Information and Communication Technologies in the Teaching and Learning of Foreign Languages: State-of-the-Art, Needs and Perspectives. Analytical Survey. UNESCO Institute for Information Technologies in Education: Moscow. 
Marcinek, A. (2014). Technology and teaching: Finding a balance. Retrieved from http://prezi.edutopia.org/blog/technology-and-teaching-finding-balanceandrew-marcinek.

Markee, N. (1997). Managing curricular innovation. Cambridge, England: Cambridge University Press.

Negoescu, A. \& Boştină-Bratu, S. (2016). Teaching and learning foreign languages with ICT. Buletin Ştiinţific, 1(41): 25-31.

Rahimi Md Saad, Zawawi Ismail \& Wan Nordin Wan Abdullah. (2005). Pengajaran dan pembelajaran bahasa Arab berasaskan web. Retrieved 10 January, 2017 from www.ipbl.edu.my/bm/penyelidikan/seminarpapers/2005/rahimiUM.pdf

Wahyu Idayu \& Yahya Buntat. (2006). Aplikasi 'e-learning' dalam pengajaran dan pembelajaran di sekolah-sekolah Malaysia: Isu dan cadangan perlaksanaannya. In Seminar TVE06, 09-10 December 2006, Hotel Sofitel Palm Resort. (Unpublished).

Waters, A. (2009). Managing innovation in English language education. Language Teaching, 42(4), 421-458.

Yakya Buntat \& Lailinanita Ahamad. (2012). Inovasi pengajaran dan pembelajaran dalam kalangan guru teknikal di sekolah menengah teknik dari perspektif guru. Journal of Technical, Vocational \& Engineering Education, 6: 44-58. 